\title{
Development of rice pre-breeding resources with blast resistance
}

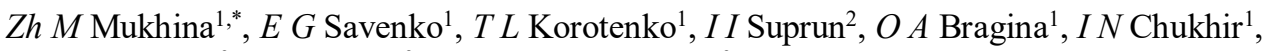 \\ Wenjing Zheng ${ }^{3}$, Ma Zuobin ${ }^{3}$, and Wang Changhua ${ }^{3}$ \\ ${ }^{1}$ Federal Scientific Rice Centre, 3, Belozerny, 350921, Krasnodar, Russia \\ ${ }^{2}$ North Caucasian Federal Scientific Center of Horticulture, Viticulture, Wine-making, 40 years of \\ Victory street, 39, 350901, Krasnodar, Russia \\ ${ }^{3}$ Liaoning Rice Research Institute, Shenyang, China
}

\begin{abstract}
Within the framework of this study, the first Russian-Chinese joint program for development of rice varieties with long-term blast resistance was launched on the basis of rice germplasm exchange and the subsequent comprehensive study of the obtained breeding samples, hybridization of Russian and Chinese varieties with specified traits. The genetic diversity of the Chinese rice samples obtained by exchange was studied by biological and morphological traits of plants, taxonomic belonging to a botanical variety, elements of the yield structure, and resistance to lodging. 31 hybrid combinations (F1) from the crossing of Russian and Chinese varieties were used to obtain the $\mathrm{BC}_{1}$ generation. The technologies of cultivation of isolated rice anthers in vitro have been optimized in relation to Chinese genotypes in order to accelerate the genetic stabilization of breeding material obtained from crossing. Phenotyping of Russian and Chinese breeding samples was carried out on the basis of resistance to the local population of the blast pathogen (Magnaporthe grisea (T.T. Hebert) M.E. Barr)), on natural and artificial infectious backgrounds. DNA identification of genes for blast resistance was carried out for the same breeding samples. Based on the experimental data obtained, promising samples were selected - prototypes of new rice varieties.
\end{abstract}

\section{Introduction}

Rice is the most important food crop in the world. It feeds more than 3 billion people and provides more than $30 \%$ of the food calories consumed by humanity. At present, rice is sown in 115 countries on an area of 156-161 million hectares, the annual grain production in the world is about 650-680 million tons. In terms of yield and gross harvest, rice takes second place after corn among all grain crops. More than $50 \%$ of the labor force of the agricultural sector of the planet is employed in rice growing. The demand for rice is growing every year, and, according to the FAO forecast, by 2020 it will reach 781 million tons, exceeding the demand for wheat by $2-3 \%$. The expected rice production of 750

\footnotetext{
* Corresponding author: agroplazma@gmail.com
} 
million tons will not be able to fully satisfy the demand for it (http://www.dsh.krasnodar.ru).

In the Russian Federation, rice is currently cultivated in 9 regions: the Republics of Adygea, Dagestan, Kalmykia, the Chechen Republic, Krasnodar, Primorsky, Astrakhan, Rostov and Jewish Autonomous Regions. Rice is not only a food product in Russia, but also plays an important role in the development of the socio-economic infrastructure of rice-growing regions. The main rice granary of the country is undoubtedly the Kuban. Rice production remains an important strategic direction for the development and recovery of the regional economy.

In China, it is the main national strategic grain crop. It is no exaggeration to say that rice is the main wealth of this country. Bowls with unleavened boiled rice are an indispensable attribute of the Chinese table. Rice cultivation area in China is currently 30 million hectares. Obviously, with this approach, the rice plant is studied comprehensively by thousands of Chinese scientists. There is a Rice Research Institute in every province in China. A vast experience of cultivation of this crop has been accumulated, genetic banks have been created, containing hundreds of thousands of valuable collection samples important pre-breeding rice resources. Over the entire period of rice cultivation in the Celestial Empire, more than 10 thousand varieties of this agricultural crop have been bred, many of which are still cultivated today. In total, over 40 thousand varieties and varieties of rice have been registered in China today. China ranks second after India in rice cultivation area, and first in production volume (http://www.chinamodern.ru/?p=18138).

At the Rice Research Institute of the Liaoning Academy of Agricultural Sciences of China, with which the Russian Federal State Budgetary Scientific Institution "Federal Scientific Rice Centrwe" has developed good partnerships, rice breeding is the main direction of the institute's activities. Modern molecular and cellular technologies are actively used in breeding schemes. The collection of original breeding material contains samples with a number of economically valuable characteristics, including a large list of samples with genes of a wide range of blast resistance. It is important to note that both in the Krasnodar region of the Russian Federation and in the Liaoning Province of China, japonica rice is grown, in contrast to the southern provinces of China (the main ricegrowing zone), where indica rice is grown. Moreover, both rice-growing regions have similar climatic conditions for rice cultivation.

This largely determines the list of common breeding tasks. In particular, the blast resistance of developed varieties. In both Liaoning Province and Krasnodar region, blast is one of the main problems in rice cultivation. In this regard, the exchange of rice genetic material, including with genes for resistance to the fungal pathogen, development of hybrid combinations based on this exchange, the exchange of breeding technologies, all this will undoubtedly bring invaluable benefits to Russian rice breeding. The first stage is a comprehensive study of rice varieties obtained by exchange under local conditions of rice cultivation in both countries. This was the main goal of this study. Blast disease (caused by the fungus Magnaporthe grisea (Herbert) Barr Yaegashi \& Udagawa (Pyricularia grisea anamorph)) is the most dangerous and harmful rice disease, widespread in most ricegrowing regions of the world, including Russia and China. The World Institute of Mycology has registered this disease in more than 80 countries. In recent years, a high severity of this disease has been noted in all rice growing zones of the world [1]. An increase in blast epiphytoties is observed in all rice-growing regions of the world. This is due, first of all, to the introduction of new technologies involving the use of high doses of mineral fertilizers, especially nitrogen fertilizers. When plants are overfed with nitrogen, the disease develops most intensively. For example, in 2013, an epiphytotic situation developed in the rice fields of the Kuban, the main Russian rice granary. More than $13 \%$ of rice crops were affected by blast disease. Loss of grain yield - 100-104 thousand tons. In 
order to limit the harmfulness of blast disease on rice crops in all countries, chemical preparations are used - fungicides. In the rice fields of the Kuban, the area of fungicidal treatments in the indicated epiphytatic year was 192 thousand hectares. (Data from the Ministry of Agriculture and Processing Industry of the Krasnodar region, 2013).

In China, the areas of fungicide treatments for blast disease are also increasing from year to year [2]. They are currently used in $70 \%$ of China's rice-growing area (usually twice per rice growing season). The increase in rice blast epiphytoties dictates the urgent need to reorient national breeding strategies towards an adaptive course and greening the industry [3]. Taking this into account, it is advisable to revise the varietal policy, giving preference to the development and introduction of rice varieties capable of producing high yields in conditions of pesticide-free (fungicides, herbicides) technologies. In addition, pesticide-free technologies in rice growing inevitably improve the purity of the waters of irrigation systems, and ultimately have a beneficial effect on the flora and fauna of the national rice-growing zones. Development of rice varieties with long-term resistance to the fungal parasite is impossible without identifying the genes responsible for this trait in the local rice-growing zones and their interaction; search for an effective breeding algorithm for the accumulation (pyramidation) of these genes on the genetic basis of the elite rice germplasm and the presence of pre-breeding resources with the specified characteristics (Rysbekova A.B. et al., 2017; Zelenskaya O.V. et al., 2018; Korotenko T.L. et al., 2018, 2019).

Long-term blast resistance cannot be ensured by the presence of one gene, since the fungus populations have the ability to mutate rapidly. For example, when variety Kati was obtained, the presence of resistant varieties would be affected (in it, the resistance gene Pita 2 ensured that this variety was noninfected by all the main races of blast in USA). However, after a few years, the variety turned out to be unstable to the newly emerging race of the pathogen [4].

One of the strategies for developing stable blast resistance is combining several resistance genes in the genotype. A number of successful breeding programs have been carried out to develop blast-resistant rice varieties by gene pyramiding using marker breeding [5-8]. An important resource for accelerated genetic stabilization of the obtained breeding material is experimental haploidy [9-13].

On the other hand, knowledge of the genetic diversity of the causative agent of the disease is an integral part of the development of resistant rice varieties [14]. The genome of the parasite is decoded [15].

Genetic certification of a pathogen in different rice-growing zones, which, first of all, is aimed at identifying the degree of genetic similarity of natural strains of the pathogen, in addition, is part of an international program for studying its global genetic diversity, creating a unified database that united the efforts of scientists from international research centers (CIRAD, IRRI). An alternative strategy is to create a collection of rice germplasm with field (horizontal) resistance to the local fungus population. Obviously, the work should be carried out in parallel, in two directions.

\section{Research goals and objectives}

1. Exchange of blast-resistant Russian and Chinese rice germplasm.

2. Evaluation of Chinese varieties for a complex of economically valuable traits in the Kuban conditions.

3. Description of phenological and morpho-biological characteristics of Chinese rice samples under conditions of Krasnodar rice cultivation. 
4. Backcrossing (obtaining $\mathrm{F}_{1}, \mathrm{BC}_{1}$ - generations) for the development of technology for introducing genes for resistance to a wide range of blast races from Chinese varieties into elite rice germplasm (varieties of Russian breeding).

5. Optimization of the technology of cultivation of isolated rice anthers in vitro in relation to Chinese rice genotypes in order to accelerate the genetic stabilization of breeding material obtained from crossing. Obtaining morphogenic callus lines and regenerant plants.

6. Phenotyping of Russian and Chinese breeding samples according to the studied trait (resistance to the local population of the blast pathogen, (Magnaporthe grisea (T.T. Hebert) M.E. Barr)), natural and artificial infectious backgrounds.

7. DNA-identification of genes for rice blast resistance in the obtained breeding samples.

8. Selection of promising samples - prototypes of new rice varieties.

\section{Materials and methods}

The rice growing zone of the Kuban is located in the third agroclimatic region, characterized by moderate moisture, the annual precipitation is $600-700 \mathrm{~mm}$. The area of the experimental production site of FSBSI "Federal Scientific Rice Centre" is characterized by a temperate continental climate, hot summers and relatively warm winters. The studies were carried out in Krasnodar region on the basis of the collection nursery of Unique scientific unit "Collection of rice genetic resources".

Samples of Chinese breeding were studied under the conditions of a field experimental irrigated plot of the Federal State Budgetary Scientific Institution "Federal Scientific Rice Centre" (Krasnodar) and vegetation experiments under the same conditions at an equal plant density and on an optimal agricultural background. The cultivation technique in the experiment corresponded to the recommendations of Federal Scientific Rice Centre. Laying of the experiment, records and observations, visual assessments, phenological observations, biometric analysis of plants were carried out according to standard methods and a classifier of the Oryza genus (VIR methods, 1982; Smetanin, 1972).

Before selecting model sheaves for biometric analysis, the resistance of plants from collection samples to lodging and grain shattering (response to environmental conditions) were assessed. The visual scoring on the plots was carried out in the phase of grain ripening from August to September. Morphological traits of grain (shape, color, pubescence, size) were evaluated in laboratory conditions after harvesting using a computer and an HP Scanjet G4050 scanner, an image analysis system.

The weight of 1000 grains was determined by counting two samples of 500 grains in a row, without selection, weighing was carried out on a Scout laboratory balance with an accuracy of $0.01 \mathrm{~g}$. The shape of a spikelet was determined visually: short-grain varieties, depending on $1 / \mathrm{b}$ (grain length to width ratio) have a rounded or oval-rounded grain, medium-grain varieties have an elongated, semi-fusiform grain, and long-grain varieties have a long, fusiform shape.

The shape and position of the panicle were assessed according to point system, where the shape of the panicle (point): 1 - compact, 3 - weakly spreading, 5 - medium-spreading, 7 - spreading; panicle position (point): 1 - vertical, 5 - inclined, 9 - drooping.

The shape of the bush was determined in points: 1 - erect bush, 3 - weakly spread, 5 medium-spread, 7 - spread bush.

\subsection{Hybridization methods}

The cultivation of parental forms for hybridization and crossing was carried out in artificial climate chambers (ACC), which are used twice a year. They have adjustable light and 
temperature modes: temperature during the day $+28-30^{\circ} \mathrm{C}$, at night $+24^{\circ} \mathrm{C}$, photoperiod duration - 12 hours, illumination - 30 thousand lux.

During the crossing period from 8 to 10 a.m., the air temperature was lowered to $+20^{\circ}$ $\mathrm{C}$ so that the high temperature (more than $30^{\circ} \mathrm{C}$ ) would not provoke the flowering of maternal forms during castration of rice flowers. The maternal and paternal forms were sown at 3 - 4 periods, one vessel at each period for the correct coordination of flowering. The dates of sowing, germination, and sweeping of parental forms were noted.

Seedlings of the maternal and paternal forms appeared in artificial climate chambers on the 5 th - 6 th day after sowing. Heading lasted for $8-10$ days.

Hybridization was performed by pneumocastration, which includes cutting the flower scales by $1 / 3$ and then removing the anthers using a vacuum compressor, which reduces damage to the stigma; then pollination by the "TVEL" method (Los G.D., 1987). After castration, the panicles were isolated in a bag (isolator) of semi-parchment paper on one side and a transparent film on the other. On the isolator, the hybridizer indicated the date of castration, the combination number, the number of castrated panicles and spikelets. Hybrid caryopses are visible through the transparent wall of the isolator on days 5-6.

During pollination, the upper part of the isolator was cut off, a flowering panicle of the paternal shape was inserted inside and turned intensively. For pollination of one combination, 1 - 2 panicles are enough.

The isolators were removed on the 30th day after castration. The number of obtained hybrid caryopses and the percentage of setting were counted. Caryopses were stored in a refrigerator.

\subsection{Cultivation of isolated rice anthers in vitro}

In the spring-summer period, donor plants were grown on vegetation plot and in the field, in the autumn-winter period - in controlled conditions of artificial climate chambers at 18$20^{\circ} \mathrm{C}$, relative humidity $70 \%$. The selection of biomaterial (immature panicles) was carried out in the morning. To stimulate the transition of the majority of microspores to the mononuclear stage, panicles with anthers were preliminarily kept at a low positive temperature of $8-10^{\circ} \mathrm{C}$ for $10-14$ days. Due to low positive temperatures, the destruction of the anther wall, which had a harmful effect on the development of microspores in culture, was delayed. This technique also made it possible to preserve the cut panicles for a long time, which is important for the mass cultivation of anthers. Before planting the anthers on artificial nutrient media, the panicles were sterilized with a commercial solution "Belizna" for 10 minutes, washed three times in sterile distilled water. For inoculation of anthers, Blades' basic agar culture medium (Blades, 1966) was used, for passaging callus, Murashige and Skoogy (Murashige and Scoogy, 1962). The media included macro- and micro-salts, Fe-chelate, organic additives (vitamins and amino acids), agar-agar and sugar. The media were autoclaved at 1.2 atmospheres for 20-25 minutes.

To stimulate cell determination and induce callusogenesis, 2,4-dichlorophenoxyacetic acid (2,4-D), thidiazuron (DROPP), and kinetin were added to Blades medium. We used 3 options of culture media:

Option 1 (control) - Blades $+2.0 \mathrm{mg} / 12,4-\mathrm{D}$;

Option 2 - Blades + $1.0 \mathrm{mg} / 12.4-\mathrm{D}+1.0 \mathrm{mg} / 1$ kinetin;

Option 3 - Blades $+1.0 \mathrm{mg} / 1$ thidiazuron.

150 anthers of each genotype were inoculated in triplicate.

All manipulations were performed under aseptic conditions in a laminar box. Anthers were cultivated in a thermostat at a temperature of $25 \pm 2{ }^{\circ} \mathrm{C}$, relative humidity $50 \%$ in the dark for 20-30 days until the formation of calli, then the calli were cultivated at a 
photoperiod of 12 hours - day (5000 lux), 12 hours - night, until the emergence of seedlings, which were transferred to a hormone-free MS medium for rooting.

\subsection{Determination of ploidy of regenerated plants}

To count the chromosomes in the roots of rice regenerants and determine the ploidy of testtube plants, the method of squashed preparations was used. A fixative was used: acetic alcohol (a solution containing $\mathrm{CH} 6 \mathrm{COOH}$ and $\mathrm{C} 2 \mathrm{H} 5 \mathrm{OH}$ ) in an acetic acid / alcohol ratio of 3: 1 . Roots $2-4 \mathrm{~mm}$ long were fixed in a refrigerator for 24 hours (at a low temperature to influence the rate of mitotic division). A macerated, acetocarmine-stained root was placed on a glass slide in a drop of $45 \%$ acetic acid, covered with a cover glass, under which it crawled into one layer of cells. They were observed on a microscope MBI-6, objectives 40x and 70x with water immersion.

Assessment of the resistance of plants in a collection nursery to damage by the pathogen Magnaporthe grisea (T.T. Hebert) M.E. Barr) on a natural background was carried out twice in the phases of heading-flowering and grain filling (period July-August). The resistance of varieties to the disease was determined by visual inspection of the entire plant for the damage of leaves, nodes, stems and panicles (Guidelines for identifying, accounting and methods for developing measures to combat rice diseases. - Krasnodar, ARRRI, 1981. 20 p.; Guidelines for diagnostics, accounting and assessment of the harmfulness of rice blast. - M., VASN named after V.I. Lenin, 1988. - 40 p.; Recommendations for the comprehensive protection of agricultural crops from pests, diseases and weeds in Krasnodar region for 2006-2012. - Krasnodar, 2006. - P. 198).

The assessment of the resistance of plants in the collection nursery to damage by the pathogen M. grisea on an artificial background was carried out twice in the phases of heading-flowering and grain filling (July-August).

Isolation, purification of strains of the blast pathogen, artificial infection and registration of plant damage in the field were carried out according to the methodological guidelines:

- Laboratory express-method for assessing rice varietal resistance to blast. - Bolshie Vyazemy, VNIIF, 1990. -11 p.;

- Guidelines for the identification, accounting and methods of developing measures to combat rice diseases. - Krasnodar, ARRRI, 1981. - P. 20;

- Recommendations for the comprehensive protection of agricultural crops from pests, diseases and weeds in the Krasnodar region for 2006-2012. - Krasnodar, 2006. - P. 198.

Scale of blast development on leaves:

0 - no damage;

1 - single brown dots or no symptoms;

2 - numerous small dots;

3 - small round spots about $2 \mathrm{~mm}$ in diameter, with a gray center and a brown border;

4 - typical spots of blast, elliptical, $1-2 \mathrm{~cm}, 2 \%$ of leaf area affected;

5 - typical spots of blast, up to $10 \%$ of the leaf area is affected;

6 - typical spots of blast, up to $25 \%$ of the leaf area is affected;

7 - typical spots of blast, up to $50 \%$ of the leaf area is affected;

8 - typical spots of blast, up to $75 \%$ of the leaf area is affected;

9 - typical spots of blast, up to $100 \%$ of the leaf area is affected.

Data on the degree of leaf damage and the number of infected plants were used to calculate the intensity of disease development using the formula 1:

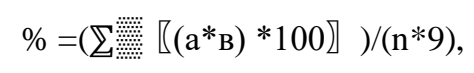

where 
$\%$ - intensity of disease development;

$\sum\left(\mathrm{a}^{*} \mathrm{~B}\right)$ - the sum of the products of the number of affected plants multiplied by the corresponding damage score;

$\mathrm{n}$ - number of counted plants, pcs.;

9 - the highest score of damage;

All samples, depending on the degree of damage, are conventionally divided into 4 groups:

$\mathrm{R}$ - resistant (0-2);

$\mathrm{M}$ - with an intermediate type of reaction (3-4);

S - susceptible (5-6);

SS - strongly susceptible (7-9) (Guidelines for the diagnosis, accounting and assessment of the harmfulness of rice blast. - M., VASN named after V.I. Lenin, 1988. - 40 p.)

\subsection{Methods of DNA identification of genes for rice blast resistance}

DNA extraction from plant material was carried out by the CTAB method (Murray M.G., Thompson W.F., 1980). The concentration of isolated DNA was determined spectrophotometrically according to the standard method (Maniatis T. et al., 1984), as well as by the intensity of DNA staining with ethidium bromide in an agarose gel (Osterman L.A., 1981). The primers used in the studies were synthesized by CJSC Syntol (Moscow). DNA amplification was performed on a Biorad T100 amplifier with individual amplification conditions for each primer. In most cases, they were optimized. PCR experiments were performed with 40-50 ng of DNA in a final volume of $25 \mu \mathrm{l}$. Used the following composition of the reaction mixture: $0.1 \mathrm{~mm}$ each deoxyribonucleoside phosphate; $0.23 \mathrm{M}$ of each primer; $1 \mathrm{x}$ PCR buffer $(20 \mathrm{mM}$ Tris-HCL, pH 8.4; $50 \mathrm{mM}$ KCL); 1 unit of Taq polymerase.

Initially, the primer annealing temperature was calculated using the Dieffenbach C.W. et al. (1995): $\mathrm{T}=4^{0} \mathrm{C} \times(\mathrm{G}+\mathrm{C})+2^{0} \mathrm{C} \times(\mathrm{A}+\mathrm{T})-3$, where $\mathrm{G}, \mathrm{C}, \mathrm{A}, \mathrm{T}-$ the number of guanidine, cytosine, adenine and thymine bases, respectively. Subsequently, it was corrected (decreased or increased) for each primer pair depending on the quality of the PCR product obtained at the calculated temperature. Thus, the optimal PCR conditions were experimentally selected to provide a high yield of the amplification product along with a minimum amount of synthesized nonspecific DNA fragments.

Electrophoresis was carried out in $3 \%$ agarose gel, based on an electrode $0.5 \times$ Trisborate buffer $(0.045 \mathrm{M}$ Tris, $0.045 \mathrm{M}$ boric acid, $1 \mathrm{mM}$ EDTA, $\mathrm{pH}=8.2)$, at a voltage of $120 \mathrm{~V}$ for 30 minutes, in chambers for horizontal electrophoresis Gel Electrophoresis Apparatus GNA-100 from Pharmacia.

PCR products mixed with the loading buffer were loaded with $10 \mu \mathrm{L}$ into the gel wells under the layer of the electrode buffer. To visualize the PCR products after electrophoresis, the gel plates were placed for 30 minutes in a solution of ethidium bromide (EtBr, 2,7diamino-10-ethyl-9-phenylphene tridinium bromide, homidium bromide) $(5 \mu \mathrm{g} / \mathrm{ml})$ and photographed in ultraviolet light. Ethidium bromide is able to intercalate into the double helix of DNA, and this binding enhances fluorescence in transmitted UV light. The allele size was determined by comparison with a standard sample - pBR322 / BsuR I (supplier company Helikon, Russia).

\section{Results}

The exchange of Russian and Chinese rice germplasm was carried out in accordance with the algorithm for sending agricultural plant seeds abroad in force in the Russian Federation and was accompanied by the presence of all the necessary permits. Samples of Chinese rice 
with blast resistance genes were grown and multiplied in the quarantine nursery of the Federal Scientific Rice Centre. The number of seeds received is shown below:

1. Liaoxing $21-60$ g; 2. Liaokai $79-76$ g; 3. Pi 9- $177-34$ g; 4 . Digu - 93 g; 5 . Gumei 4 - 32 g; 6. BL 122 - 49 g;7. Ganguu 129 - 49 g; 8. Longgeng $39-9$ g; 9 . Liaoxing $401-$ $31 \mathrm{~g} ; 10$. Kendao $34-13$ g; 11. Ganguan 8 - 30 g; 12. Rongguang - 18 g; 13. Fuguo - 5 g; 14. Hejiang $20-31$ g; 15. Longjing $3-5$ g; 16. Suijing $5-8$ g; 17. Kenddao $8-12$ g; 18 . Dongnong 416 - 10 g; 19. Tianjing $1-41$ g; 20. Jida $818-39$ g; 21 . Tongyu $401-25$ g; 22. Lx1-23 g; 23. Liaojing $168-23$ g; 24. Liaoxing $21-85$ g; 25 . HY - 74 g.

For study in an infectious nursery (natural infectious background) at the breeding station of the Liaoning Rice Research Institute (in the southern province of PRC), the following rice varieties (accessions) of Russian breeding, possessing field (horizontal) resistance to the Krasnodar population of the blast pathogen were transferred: Liman, Rapan, Lider, Atlas, Sonnet, Sonata, Flagman, Krepysh, Privolny 4, Kurazh.

\subsection{Characteristic of the morpho-biological traits of Chinese rice samples under the conditions of Krasnodar region}

The genetic diversity of Chinese rice accessions was studied by biological and morphological traits of plants, taxonomic affiliation to a botanical variety, elements of yield structure, and resistance to lodging. Table 1 shows the results of evaluating Chinese lines for some significant breeding traits.

Table 1. Characteristic of Chinese rice samples by biological and morphological traits of plants in a field experiment, irrigated plot of FSBSI "Federal Scientific Rice Centre", 2019- 2020.

\begin{tabular}{|c|c|c|c|c|c|c|c|c|}
\hline 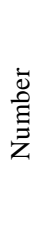 & 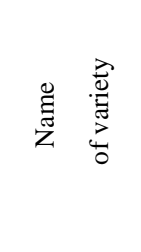 & 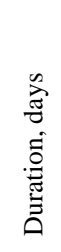 & 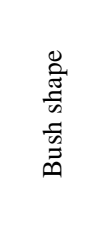 & 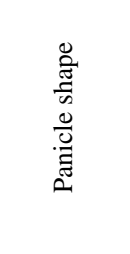 & 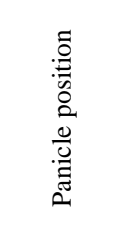 & 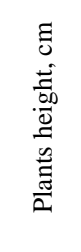 & 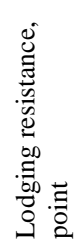 & 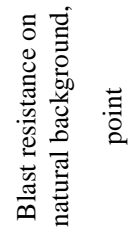 \\
\hline 1 & Kendao 34 & 112 & erect & $\begin{array}{c}\text { weakly } \\
\text { spreading }\end{array}$ & drooping & $57-63$ & 3 & 5 \\
\hline 2 & $\begin{array}{c}\text { Longgeng } \\
31\end{array}$ & - & - & - & - & - & - & - \\
\hline 3 & $\begin{array}{c}\text { Longgeng } \\
39\end{array}$ & 107 & erect & $\begin{array}{c}\text { weakly } \\
\text { spreading }\end{array}$ & inclined & $70-73$ & 1 & 3 \\
\hline 4 & $\begin{array}{c}\text { Liaoxing } \\
21\end{array}$ & 135 & erect & compact & vertical & $78-82$ & 3 & 1 \\
\hline 5 & $\begin{array}{c}\text { Liaoxing } \\
401\end{array}$ & 127 & erect & compact & inclined & $60-65$ & 1 & 1 \\
\hline 6 & Liaokai 79 & 135 & erect & compact & inclined & $67-72$ & 1 & 1 \\
\hline 7 & BL 122 & 137 & erect & $\begin{array}{l}\text { medium } \\
\text { spreading }\end{array}$ & drooping & $60-63$ & 1 & 3 \\
\hline 8 & Gumei 4 & 138 & erect & $\begin{array}{c}\text { weakly } \\
\text { spreading }\end{array}$ & inclined & $67-72$ & 3 & 3 \\
\hline 9 & Digu & 115 & erect & $\begin{array}{l}\text { medium } \\
\text { spreading }\end{array}$ & drooping & $42-45$ & 1 & 1 \\
\hline 10 & Pi 9-177 & 120 & $\begin{array}{l}\text { weakly } \\
\text { spread }\end{array}$ & $\begin{array}{l}\text { medium } \\
\text { spreading }\end{array}$ & inclined & $68-75$ & 3 & 5 \\
\hline 11 & $\begin{array}{c}\text { Gangyu } \\
129\end{array}$ & 145 & erect & $\begin{array}{c}\text { weakly } \\
\text { spreading }\end{array}$ & inclined & $56-72$ & 1 & 1 \\
\hline 12 & Ganguan 8 & 138 & erect & compact & inclined & $80-87$ & 1 & 1 \\
\hline
\end{tabular}




\begin{tabular}{|c|c|c|c|c|c|c|c|c|}
\hline 13 & Ronguang & 115 & erect & $\begin{array}{c}\text { weakly } \\
\text { spreading }\end{array}$ & drooping & $72-80$ & 3 & 5 \\
\hline 14 & Fuguo & 115 & erect & $\begin{array}{c}\text { weakly } \\
\text { spreading }\end{array}$ & drooping & $52-56$ & 1 & 3 \\
\hline 15 & Hejiang 20 & 120 & erect & compact & vertical & $63-74$ & 1 & 1 \\
\hline 16 & Longjing 3 & 98 & erect & $\begin{array}{c}\text { weakly } \\
\text { spreading }\end{array}$ & drooping & $85-92$ & 1 & 1 \\
\hline 17 & Suijing 5 & 105 & erect & $\begin{array}{c}\text { weakly } \\
\text { spreading }\end{array}$ & drooping & $64-72$ & 1 & 3 \\
\hline 18 & Kenddao 8 & 108 & erect & $\begin{array}{c}\text { weakly } \\
\text { spreading }\end{array}$ & drooping & $45-50$ & 1 & 3 \\
\hline 19 & $\begin{array}{c}\text { Dong nong } \\
416 \\
\end{array}$ & 110 & erect & $\begin{array}{c}\text { weakly } \\
\text { spreading }\end{array}$ & inclined & $45-62$ & 1 & 3 \\
\hline 20 & Tianjing 1 & 116 & erect & compact & inclined & $78-83$ & 1 & 5 \\
\hline 21 & Jida 818 & 110 & erect & $\begin{array}{c}\text { weakly } \\
\text { spreading }\end{array}$ & inclined & $68-74$ & 1 & 3 \\
\hline 22 & $\begin{array}{c}\text { Tonggyu } \\
401\end{array}$ & 116 & erect & $\begin{array}{c}\text { weakly } \\
\text { spreading }\end{array}$ & drooping & $52-55$ & 1 & 1 \\
\hline 23 & $\begin{array}{c}\text { Liaojing } \\
168 \\
\end{array}$ & 126 & erect & compact & vertical & $55-62$ & 1 & 3 \\
\hline 24 & $\begin{array}{c}\text { Liaoxing } \\
21 \\
\end{array}$ & 123 & erect & compact & inclined & $73-82$ & 1 & 1 \\
\hline 25 & HY11 & 124 & erect & compact & inclined & $67-70$ & 1 & 3 \\
\hline 26 & LX1 & 155 & erect & compact & vertical & $48-54$ & 1 & 1 \\
\hline 27 & Avangard & 119 & erect & $\begin{array}{l}\text { medium } \\
\text { spreading }\end{array}$ & drooping & $110-119$ & 1 & 1 \\
\hline 28 & Pobeda 65 & 105 & erect & compact & vertical & $85-89$ & 1 & 5 \\
\hline
\end{tabular}

The grain of the studied Chinese rice samples is rough in pubescence, scales are straw colored, the spikelet is rounded-oval in shape. No long-grained forms were found among the Chinese germplasm (table 2).

Table 2. Characteristics of the morphological traits of plants and grain morphology of Chinese rice samples, irrigated plot of FSBSI "Federal Scientific Rice Centre", 2019-2020.

\begin{tabular}{|c|c|c|c|c|c|c|c|}
\hline 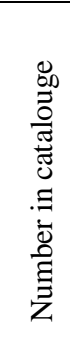 & 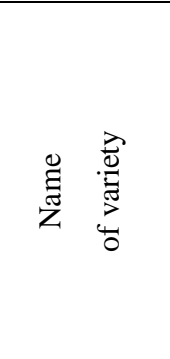 & 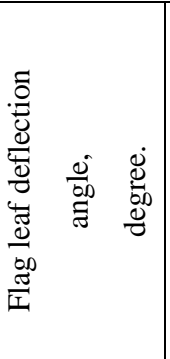 & 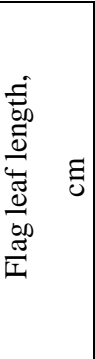 & 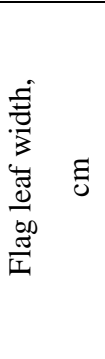 & 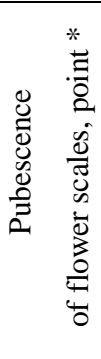 & 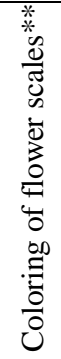 & 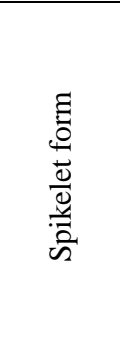 \\
\hline 1 & Kendao 34 & $45-60$ & $28-35$ & 1.0 & 5 & LS & $\begin{array}{c}\text { roundish- } \\
\text { oval }\end{array}$ \\
\hline 2 & Longgeng 31 & - & - & - & - & - & - \\
\hline 3 & Longgeng 39 & $30-45$ & $22-27$ & 1.1 & $5-7$ & LS & roundish \\
\hline 4 & Liaoxing 21 & $20-25$ & $19-22$ & 1.6 & 5 & LB & oval \\
\hline 5 & Liaoxing 401 & $10-20$ & $13-18$ & 1.1 & 5 & LS & $\begin{array}{l}\text { roundish- } \\
\text { oval }\end{array}$ \\
\hline 6 & Liaokai 79 & $25-30$ & $15-18$ & 1.2 & 5 & LS & $\begin{array}{l}\text { roundish- } \\
\text { oval }\end{array}$ \\
\hline 7 & BL 122 & $35-45$ & $18-21$ & 0.8 & 3 & LB & oval \\
\hline
\end{tabular}




\begin{tabular}{|c|c|c|c|c|c|c|c|}
\hline 8 & Gumei 4 & $15-20$ & $20-24$ & 1.5 & 3 & LS & oval \\
\hline 9 & Digu & $10-15$ & $19-23$ & 1.2 & 3 & GY & oval \\
\hline 10 & Pi 9-177 & $15-20$ & $24-30$ & 1.8 & 3 & LS & $\begin{array}{l}\text { roundish- } \\
\text { oval }\end{array}$ \\
\hline 11 & Gangyu 129 & $10-20$ & $23-26$ & 1.8 & 3 & LS & $\begin{array}{l}\text { roundish- } \\
\text { oval }\end{array}$ \\
\hline 12 & Ganguan 8 & $15-20$ & $20-26$ & 1.4 & 5 & LS & $\begin{array}{l}\text { roundish- } \\
\text { oval }\end{array}$ \\
\hline 13 & Ronguang & $30-45$ & $25-27$ & 1.4 & 5 & LS & $\begin{array}{l}\text { roundish- } \\
\text { oval }\end{array}$ \\
\hline 14 & Fuguo & $30-45$ & $27-32$ & 1.1 & 5 & LY & $\begin{array}{l}\text { roundish- } \\
\text { oval }\end{array}$ \\
\hline 15 & Hejiang 20 & $20-35$ & $23-27$ & 1.0 & 5 & LY & oval \\
\hline 16 & Longjing 3 & $30-35$ & $24-28$ & 1.7 & 5 & LB & $\begin{array}{l}\text { roundish- } \\
\text { oval } \\
\end{array}$ \\
\hline 17 & Suijing 5 & $65-80$ & $29-32$ & 1.1 & 5 & LY & oval \\
\hline 18 & Kenddao 8 & $30-45$ & $18-24$ & 1.1 & 5 & LS & $\begin{array}{l}\text { roundish- } \\
\text { oval }\end{array}$ \\
\hline 19 & $\begin{array}{c}\text { Dong nong } \\
416 \\
\end{array}$ & $30-45$ & $21-27$ & 1.1 & 5 & LY & $\begin{array}{l}\text { roundish- } \\
\text { oval }\end{array}$ \\
\hline 20 & Tianjing 1 & $10-25$ & $21-25$ & 1.4 & $5-7$ & LY & oval \\
\hline 21 & Jida 818 & $10-25$ & $16-23$ & 1.2 & 5 & LY & $\begin{array}{l}\text { roundish- } \\
\text { oval }\end{array}$ \\
\hline 22 & Tonggyu 401 & $10-20$ & $22-28$ & 1.2 & 5 & LS & $\begin{array}{l}\text { roundish- } \\
\text { oval }\end{array}$ \\
\hline 23 & Liaojing 168 & $10-15$ & $12-15$ & 1.1 & 5 & LS & $\begin{array}{l}\text { roundish- } \\
\text { oval }\end{array}$ \\
\hline 24 & Liaoxing 21 & $5-10$ & $16-24$ & 1.5 & 5 & LY & oval \\
\hline 25 & HY11 & $5-10$ & $15-19$ & 1.3 & 5 & LS & $\begin{array}{l}\text { roundish- } \\
\text { oval }\end{array}$ \\
\hline 26 & LX1 & $5-15$ & $14-16$ & 1.3 & 5 & LS & $\begin{array}{l}\text { roundish- } \\
\text { oval }\end{array}$ \\
\hline 27 & $\begin{array}{c}\text { Avangard } \\
04656 \\
\end{array}$ & $40-45$ & $35-40$ & 1.3 & 7 & LY & oval \\
\hline 28 & $\begin{array}{c}\text { Pobeda } 65- \\
04655 \\
\end{array}$ & $15-20$ & $15-18$ & 1.2 & 7 & $\mathrm{~S}$ & oval \\
\hline
\end{tabular}

\subsection{Assessment of economically valuable traits of Chinese rice samples in Krasnodar region}

The elements of plant productivity of the studied rice genotypes were determined in the laboratory by biometric analysis of the selected sheaves (10 plants per plot). The results of the assessment of economically valuable traits of Chinese varieties are presented in table 3 . 
Table 3. Characteristics of Chinese samples by economically valuable traits, irrigated plot of FSBSI

"Federal Scientific Rice Centre", 2019-2020.

\begin{tabular}{|c|c|c|c|c|c|c|c|c|c|}
\hline $\begin{array}{l}\overline{\mathbf{D}} \\
\text { 节 } \\
\text { z }\end{array}$ & 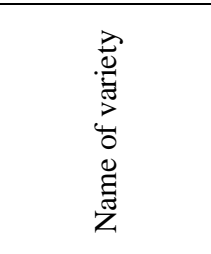 & 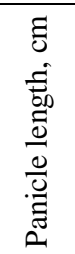 & 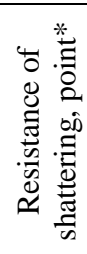 & 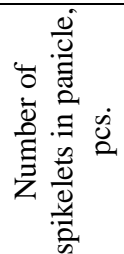 & 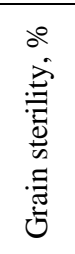 & 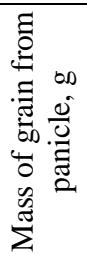 & 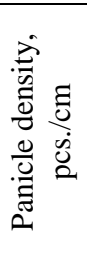 & 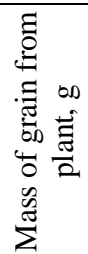 & 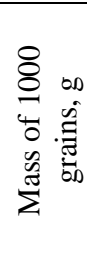 \\
\hline 1 & Kendao 34 & 17,5 & 1 & 74,0 & 8,6 & 2,03 & 4,6 & 3,2 & 27,4 \\
\hline 2 & Longgeng 31 & - & - & - & - & - & - & - & - \\
\hline 3 & Longgeng 39 & 16,0 & 1 & 124,0 & 5,3 & 2,83 & 8,2 & 3,9 & 22,7 \\
\hline 4 & Liaoxing 21 & 16,6 & 1 & 121,0 & 6,9 & 2,94 & 7,3 & 4,0 & 24,3 \\
\hline 5 & Liaoxing 401 & 16,2 & 1 & 107,0 & 15.7 & 2,48 & 7,9 & 3,5 & 23,2 \\
\hline 6 & Liaokai 79 & 18,4 & 1 & 111,0 & 11,2 & 3,08 & 6,0 & 4,1 & 27,7 \\
\hline 7 & BL 122 & 22,5 & 5 & 100,0 & 35,0 & 1,83 & 4,4 & 3,0 & 18,3 \\
\hline 8 & Gumei 4 & 19,8 & 5 & 94,0 & 30,8 & 1,98 & 4,7 & 3,0 & 21,1 \\
\hline 9 & Digu & 16,1 & 5 & 78,0 & 10,2 & 1,35 & 4,8 & 2,4 & 19,2 \\
\hline 10 & Pi 9-177 & 15,8 & 1 & 175,0 & 10,2 & 3,71 & 12,3 & 4,7 & 21,2 \\
\hline 11 & Gangyu 129 & 18,5 & 1 & 148,0 & 24,5 & 3,25 & 8,0 & 4,3 & 22,0 \\
\hline 12 & Ganguan 8 & 17,0 & 1 & 122,0 & 8,3 & 3,02 & 7,2 & 4,1 & 24,8 \\
\hline 13 & Ronguang & 17,1 & 1 & 98,0 & 10,9 & 2,50 & 6,4 & 3,5 & 25,5 \\
\hline 14 & Fuguo & 18,4 & 1 & 104,0 & 7,9 & 2,40 & 6,1 & 4,4 & 23,1 \\
\hline 15 & Hejiang 20 & 16,1 & 1 & 84,0 & 13,4 & 1,52 & 5.8 & 2,6 & 18,1 \\
\hline 16 & Longjing 3 & 16,3 & 1 & 120,0 & 14,8 & 2,62 & 7,4 & 3,7 & 21,8 \\
\hline 17 & Suijing 5 & 17,5 & 1 & 87,0 & 8,4 & 2.19 & 5,5 & 3,2 & 25,2 \\
\hline 18 & Kenddao 8 & 13,2 & 1 & 50,0 & 7,4 & 1,33 & 4,1 & 2.4 & 26,6 \\
\hline 19 & Dong nong 416 & 16,0 & 1 & 74,0 & 9,7 & 1,76 & 5,1 & 2,8 & 23,7 \\
\hline 20 & Tianjing 1 & 15,8 & 1 & 89,0 & 16,0 & 1,75 & 6,7 & 2,9 & 19,6 \\
\hline 21 & Jida 818 & 15,1 & 1 & 83,0 & 19,4 & 1.78 & 6.8 & 2,8 & 21,4 \\
\hline 22 & Tonggyu 401 & 16,6 & 1 & 103,0 & 6,3 & 2,58 & 6.6 & 3,6 & 25,0 \\
\hline 23 & Liaojing 168 & 14,3 & 1 & 102,0 & 8,9 & 2,52 & 7,8 & 3,7 & 24,7 \\
\hline 24 & Liaoxing 21 & 18,5 & 1 & 150,0 & 16,6 & 3,30 & 8,1 & 4,3 & 22,1 \\
\hline 25 & HY11 & 16,4 & 1 & 111,0 & 6,7 & 2,65 & 7,3 & 3,8 & 23,8 \\
\hline 26 & Avangard & 19,6 & 3 & 72,0 & 23,4 & 2,46 & 4,8 & 3,6 & 34,1 \\
\hline 27 & Pobeda 65 & 14,2 & 3 & 134,0 & 9,2 & 3,05 & 7,6 & 4,1 & 22,4 \\
\hline \multirow[t]{2}{*}{28} & LX1 & 18,0 & 1 & 181,0 & 5,5 & 3,98 & 10,0 & 4,9 & 22,0 \\
\hline & $\operatorname{LSD}_{05}$ & 1,3 & & 8,4 & & 0,32 & & & \\
\hline
\end{tabular}

\subsection{Crossing Chinese and Russian rice samples. Obtaining $F_{1} B_{1}-$ generations}

Crossings of samples of Federal Scientific Rice Centre with Chinese samples were carried out, in 201931 hybrid combinations $\left(F_{1}\right)$ were obtained. Of these combinations of crosses, breeders selected 16 to obtain $\mathrm{BC}$ generations (backcrossing) with the subsequent obtaining $\mathrm{BC}_{1}$ in 2020. 


\subsection{Optimization of cultivation technology of isolated rice anthers in vitro in relation to the studied genotypes (Chinese rice samples). Obtaining morphogenic callus lines and regenerants}

During the rapid determination of the stage of development, rice microspores were squeezed out of the anthers onto a glass slide under a stereomicroscope, a drop of acetocarmine was added, covered with a cover glass and microscoped at 200 and 400 times magnification. The stage of development was determined by the shape of the microspores. Anthers for cytological control were taken from the beginning of the emergence of the flag from the boot until the appearance of the upper spikelets.

We studied the responsiveness of Chinese rice genotypes with blast resistance genes Pigy8, Pita, Ptr to anther culture in vitro in order to obtain morphogenic callus lines and accelerate development of genetically stable (homozygous) DH lines (doubled haploids) with high morphological evenness by experimental haploidy (tables 4, 5, 6). The experiment showed that Blades medium with $2.0 \mathrm{mg} / 1$ of phytohormone 2,4-D is most suitable for cultivating rice anthers, as it stimulates the induction of callusogenesis in most genotypes and affects the subsequent regeneration of plants from callus cells. The best results in the realization of form-forming potencies and plant regeneration from calli of the studied genotypes were achieved on the Murashige and Skoog nutrient medium with 1.0 $\mathrm{mg} / \mathrm{l} \alpha$-NAA and $5.0 \mathrm{mg} / 1$ kinetin.

Table 4. Callusogenesis of Chinese rice samples.

\begin{tabular}{|c|c|c|c|c|}
\hline \multirow{2}{*}{ № } & \multirow{2}{*}{ Name of combination } & \multicolumn{3}{|c|}{ Callusigenesis, \% } \\
\cline { 3 - 5 } & & 1option (control) & 2 option & 3 option \\
\hline 1. & Liaojing 168 & 15,92 & 9,54 & 0 \\
\hline 2. & Liaoxing 21 & 7,31 & 0 & 0 \\
\hline 3. & HY 11 & 9,72 & 0 & 0 \\
\hline \multicolumn{2}{|c|}{} \\
\hline
\end{tabular}

Callusogenesis was induced on the 20th - 40th day. The quality and number of calli were recorded for each sample. The variability in callus formation and regeneration was genetically determined. As can be seen from tables 5 and 6, the indices of callusogenesis and regeneration differed between the studied samples; they also varied between different donor plants of the same sample.

Table 5. Influence of Oryza sativa L. genotype on callusogenesis in isolated anthers culture, \%.

\begin{tabular}{|c|c|c|c|}
\hline \multirow{2}{*}{ № } & \multirow{2}{*}{ Name of sample } & \multicolumn{2}{|c|}{ Callusogenesis, $\%$} \\
\hline & & $\min$ & $\max$ \\
\hline 1. & Liaojing 168 & 3,21 & 11,85 \\
\hline 2. & Liaoxing 21 & 0,37 & 1,47 \\
\hline 3. & HY 11 & 1,94 & 3,64 \\
\hline & & $\mathrm{LSD}_{0,05}$ & \\
\hline
\end{tabular}

The sample Liaojing 168 was the most responsive to anther culture in vitro, in which the maximum callusogenesis was noted; the weakest response to culture introduction was observed in sample Liaoxing 21. 
Table 6. Influence of Oryza sativa L. genotype on regeneration in isolated anthers culture, $\%$.

\begin{tabular}{|c|c|c|c|}
\hline \multirow{2}{*}{ № } & \multirow{2}{*}{ Name of sample } & \multicolumn{2}{|c|}{ Regeneration, \% } \\
\cline { 3 - 4 } & & $\min$ & $\max$ \\
\hline 1. & Liaojing 168 & 0,98 & 1,47 \\
\hline 2. & Liaoxing 21 & 0,07 & 0,33 \\
\hline 3. & HY 11 & 0,94 & 1,16 \\
\hline \multicolumn{3}{|c|}{0,02} \\
\hline
\end{tabular}

\subsection{Phenotyping of the Chinese rice samples obtained from the exchange according to the studied trait (resistance to the local population of the blast pathogen, artificial background) on the territory of Russian rice growing zone (Krasnodar region) under the conditions of a vegetation experiment}

\subsubsection{Obtaining an inoculum for cultivation of the causative agent of rice blast disease - a phytopathogenic fungus (Magnaporthe grisea (T.T. Hebert) M.E. Barr)}

To identify the pathogen and study the composition of the population of the blast pathogen during the entire period of the development of the disease, route surveys of rice crops were carried out to collect samples of infected rice in the rice-growing districts of Krasnodar region - Slavyansky, Krymsky, Krasnoarmeysky, Abinsky and on experimental plot of Federal Scientific Rice Centre (Krasnodar, Belozerny. Fungus culture was isolated from the leaves, nodes and panicles of plants. 4 clearly differentiated strains of the pathogen with different sporulating ability were isolated and purified.

\subsubsection{Assessment of Chinese rice samples against artificial infectious background}

The immunological assessment was based on the creation of a severe infectious background and provocative conditions (increased nitrogen background and thickened crops) during the cultivation of rice culture. To create an increased nitrogen background, contributing to the better development of blast disease, urea was used. The main dose of nitrogen $(50 \%$ of the total dose) was introduced into the vessels before sowing rice with incorporation into the soil, the rest was used as top dressing at two times: at seedlings and one week before inoculation. The annual collection of blast-infected material in the fields of rice-growing farms of the region ensured the high quality of the Krasnodar population of the pathogen used to create an infectious background.

\subsubsection{Artificial inoculation of plants}

Plants are inoculated in the most vulnerable phases of rice development: tillering (5-7 leaves), emergence - flowering with a spore suspension. To obtain a suspension for artificial infection a mixture of dry spore material and a 14-day culture of the fungus on carrot agar is used. On the day of inoculation, spores are washed off with distilled water and the spore concentration is adjusted to 105 spores per ml. Inoculation of plants on the plots is carried out in the evening, in the period of dew and in the absence of wind, a suspension is sprayed evenly on each plot. (Note: successful infection occurs when the duration of the dew period is not less than 8-10 hours, frequent light rain, fog at a temperature of $25-28^{\circ} \mathrm{C}$. In the absence of natural dew, rice plants are sprayed with water before inoculation). Plants in vessels before infection were placed in a special frame 
covered with plastic wrap to maintain the optimum temperature and humidity, which would facilitate effective infection of plants.

\subsubsection{Assessment of the degree of resistance of rice samples}

Account of plants damage by blast was carried out during two growing seasons, twice per season, 10 and 20 days after inoculation (table 7).

Table 7. Assessment of resistance of Chinese rice varieties to the Krasnodar population of rice blast pathogen (artificial background), 2019- 2020.

\begin{tabular}{|c|c|c|c|c|}
\hline \multirow{2}{*}{ № } & \multirow{2}{*}{ No Number in catalouge } & \multirow{2}{*}{ Name of sample } & \multicolumn{2}{|c|}{ Reaction } \\
\cline { 4 - 5 } & & & 2019 & 2020 \\
\hline 1 & 14102 & Kendao 34 & $\mathrm{S}$ & $\mathrm{S}$ \\
\hline 2 & 14404 & Longgeng 39 & $\mathrm{M}$ & $\mathrm{M}$ \\
\hline 3 & 14405 & Liaoxing 21 & $\mathrm{M}$ & $\mathrm{M}$ \\
\hline 4 & 14406 & Liaoxing 401 & $\mathrm{M}$ & $\mathrm{M}$ \\
\hline 5 & 14407 & Liaokai 79 & $\mathrm{M}$ & $\mathrm{M}$ \\
\hline 6 & 14408 & BL 122 & $\mathrm{M}$ & $\mathrm{M}$ \\
\hline 7 & 14409 & Gumei 4 & $\mathrm{M}$ & $\mathrm{M}$ \\
\hline 8 & 14410 & Digu & $\mathrm{M}$ & $\mathrm{M}$ \\
\hline 9 & 14411 & Pi-9 177 & $\mathrm{M}$ & $\mathrm{M}$ \\
\hline 10 & 14413 & Gangyuan 8 & $\mathrm{M}$ & $\mathrm{M}$ \\
\hline 11 & 14144 & Rongyuang & $\mathrm{M}$ & $\mathrm{M}$ \\
\hline 12 & 14145 & Fuguo & $\mathrm{M}$ & $\mathrm{M}$ \\
\hline 13 & 14146 & Hejiang 20 & $\mathrm{M}$ & $\mathrm{M}$ \\
\hline 14 & 14148 & Suijing 5 & $\mathrm{M}$ & $\mathrm{M}$ \\
\hline 15 & 14149 & Kenddao 8 & $\mathrm{R}$ & $\mathrm{R}$ \\
\hline 16 & 14150 & Dongnong 416 & $\mathrm{M}$ & $\mathrm{M}$ \\
\hline 17 & 14151 & Tianjing 1 & $\mathrm{MS}$ & $\mathrm{MS}$ \\
\hline 18 & 14152 & Juda 818 & $\mathrm{M}$ & $\mathrm{M}$ \\
\hline 19 & 14153 & Tongyu 401 & $\mathrm{R}$ & $\mathrm{R}$ \\
\hline 20 & 14155 & Liojing 168 & $\mathrm{R}$ & $\mathrm{R}$ \\
\hline 21 & 14156 Pi-ta & CO39 & $\mathrm{R}$ & $\mathrm{R}$ \\
\hline 22 & & & $\mathrm{~S}$ & $\mathrm{~S}$ \\
\hline 23 & Pobeda 65 st. & $\mathrm{R}$ & $\mathrm{R}$ \\
\hline 24 & Avangard st. & & $\mathrm{S}$ \\
\hline
\end{tabular}

The phytopathological assessment showed that, during two growing seasons, varieties of Chinese breeding mainly showed an intermediate type of reaction.

\subsection{Molecular-genetic identification of rice blast resistance genes in studied rice samples}

Molecular genetic identification of genes for rice blast resistance of samples from the collection of genetic resources of FSBSI Federal Scientific Rice Centre as well as Chinese samples. The studied samples included 41 genotypes. Fig. 1, 2, 3 show electrophoregrams of PCR products by DNA markers of Pi-z, Pi-ta and Pi-b genes. 


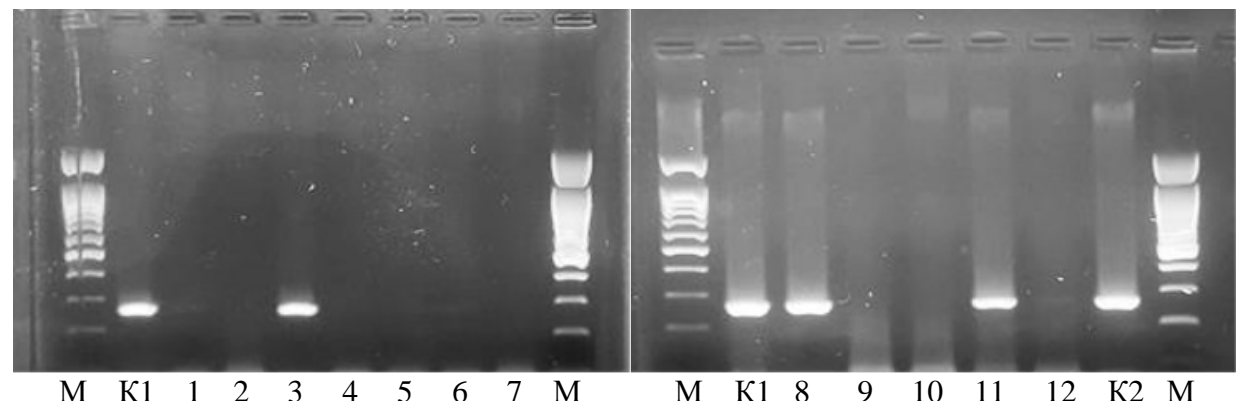

Fig. 1. Electrophoretic separation of PCR products by DNA marker of the Pi-z gene. M - marker of DNA molecular weight, K1 - positive control (variety Zenit-donor of Pi-z gene), K2 - positive control (collection sample №98-4-donor of Pi-z gene); 1-12 studied varieties and collection samples 1 - Long Jing 15, 2- Mu07-980, 3- Long Jing 13, 4- Mu07-1049, 5- Long Jing 12, 6-K04-38, 7 K247-06, 8 - VNIIR 6753, 9 -K236-09, 10 -K84-07, 11 - IRIS 251-53324-Takanari, 12 -K546-10.

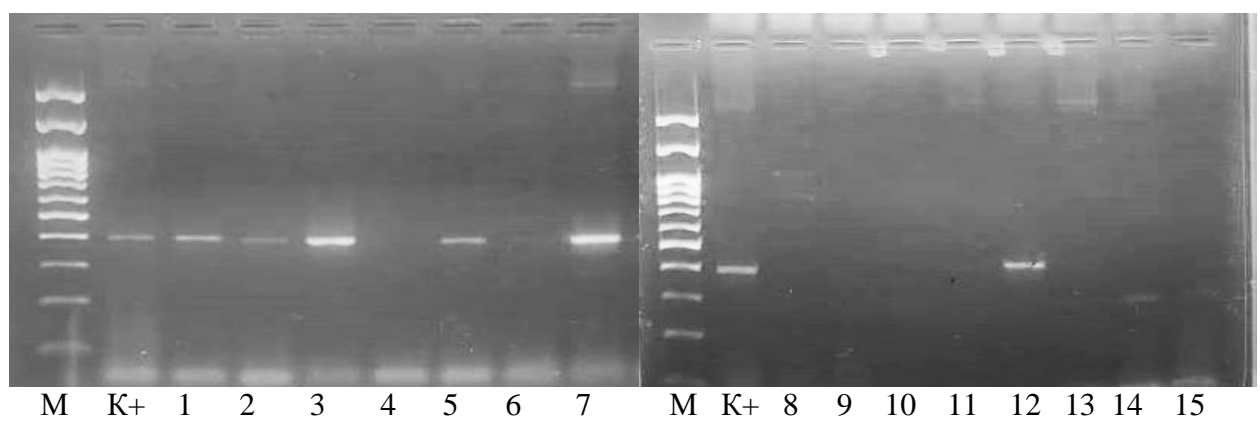

Fig. 2. Electrophoretic separation of PCR products by DNA marker of the Pi-ta gene. M - marker of DNA molecular weight, $\mathrm{K}+-$ positive control (sample K24-14 - donor of Pi-ta gene), 1-12 studied varieties and collection samples: 1- Long Jing 16, 2- Long Jing 20, 3- Мu 07-1111, 4- Рапан, 5Deshan B, 6- Mu 07-1055, 7 - Long Jing 18, 8 - G-46-B, 9 - ВНИИР 40/4-1, 10 - Dong Nong 416, 11 - Zhongyon ZH3, 12 - Xieyov, 13 - Zaoxian 14, 14 - K108-11 Lider/Takanari-2, 15 - IRIS 251-53325 Takanari.
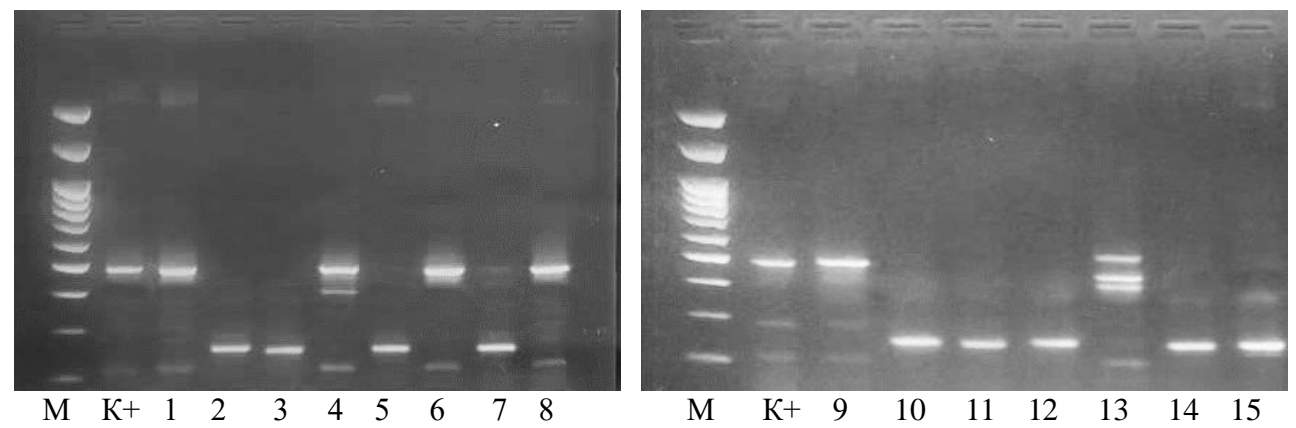

Fig. 3. Electrophoretic separation of PCR products by DNA marker of the $P i-b$ gene. M - marker of DNA molecular weight, $\mathrm{K}+-$ positive control (sample K27-14-donor of Pi- $b$ gene), 1-12 studied varieties and collection samples: 1- K54-14, 2- Tong Jing 29, 3- Dong Nong V7, 4-933B, 5- K03-99Deshan B, 6- K107-11 Lider/Takanari, 7 - Ji Sheng 202, 8 - VNIIR 6753, 9 - Long Jing 16, 10 - Long Jing 20, 11 - Mu 07-1111, 12 - Rapan, 13 -K04207, 14- Mu 07-1055, 15 - Long Jing 18. 
The summary results of DNA marker identification of target blast resistance genes are shown in table 8.

Table 8. Results of DNA marker analysis for target genes of rice blast resistance.

\begin{tabular}{|c|c|c|c|c|}
\hline \multirow{2}{*}{ № } & \multirow{2}{*}{ Sample } & \multicolumn{3}{|c|}{ Gene } \\
\hline & & $\mathrm{Pi}-\mathrm{z}$ & Pi-b & Pi-ta \\
\hline 1. & 04688 (175-2-09 - Long Jing 16) & - & + & + \\
\hline 2. & 04695 (175-5-09 - Long Jing 20) & - & - & + \\
\hline 3. & 04693 (180-3-09 - Mu 07-1111) & - & - & + \\
\hline 4. & 04207 (Deshan B) & - & - & + \\
\hline 5. & $04650(\mathrm{Mu} 07-1055)$ & - & - & - \\
\hline 6. & 04683 (175-3-09 - Long Jing 18) & - & - & + \\
\hline 7. & 93133 (Dong 415) & - & - & + \\
\hline 8. & 04689 (175-1-09- Long Jing 15) & - & - & + \\
\hline 9. & $04649(\mathrm{Mu} 07-980)$ & - & - & - \\
\hline 10. & 04698 (170-3-09- Long Jing 13) & + & - & + \\
\hline 11. & 04694 (180-2-09-Mu 07-1049) & - & - & + \\
\hline 12. & 04692 (170-2-09 - Long Jing 12) & - & - & + \\
\hline 13. & 04-38 (NSR 00252 Csing Feng 2) & - & & - \\
\hline 14. & 247-06 (Qianyon 1) & - & - & - \\
\hline 15. & 255-05 (Dong Nong 416) & - & - & - \\
\hline 16. & $549-10(\mathrm{G}-46-\mathrm{B})$ & - & + & - \\
\hline 17. & 245-06 (Zhongyon ZH3) & - & - & - \\
\hline 18. & 244-06 (Xieyov) & - & + & + \\
\hline 19. & 246-11 (AA 42708/10 Zaoxian 14) & - & - & - \\
\hline 20. & 96-11 (IRIS 251-53325 Takanari) & - & + & - \\
\hline 21. & 235-09 (Tong Jing 29) & + & - & - \\
\hline 22. & 253-05 (Dong Nong V7) & - & - & + \\
\hline 23. & $552-10(933 \mathrm{~B})$ & - & + & - \\
\hline 24. & 03-99 (Deshan B) & - & - & - \\
\hline 25. & 234-09 (Ji Sheng 202) & - & - & - \\
\hline 26. & 236-09 (Chang Bai) & - & - & - \\
\hline 27. & 84-07 (Xiaoma CU ACL 56158) & - & - & - \\
\hline 28. & 91-11 (IRIS 251-53324- Takanari) & + & + & - \\
\hline 29. & $546-10(611 \mathrm{~B})$ & - & + & - \\
\hline 30. & ВНИИР 40/4-1 & - & + & - \\
\hline 31. & 108-11 (Lider/Takanari-2) & - & + & - \\
\hline 32. & 107-11 (Lider/Takanari) & + & + & - \\
\hline 33. & VNIIR 6753 & + & - & - \\
\hline 34. & 04062 (Rapan) & - & - & - \\
\hline 35. & 04222 (Sonata) & - & - & - \\
\hline 36. & 01252 (Liman) & - & - & - \\
\hline 37. & 04197 (Atlant) & - & - & - \\
\hline
\end{tabular}




\begin{tabular}{|r|c|c|c|c|}
\hline 38. & 04667 (Privolny 4$)$ & - & - & - \\
\hline 39. & $04670($ Kurazh $)$ & - & - & - \\
\hline 40. & 04220 (Sonet) & - & - & - \\
\hline 41. & 04666 (Krepysh) & - & - & - \\
\hline
\end{tabular}

In the table, the "+" sign indicates the presence of an amplification fragment corresponding to the dominant allele of the desired genes. It can be seen that in a number of samples the target fragments were identified simultaneously for two genes. In samples Long jing 16 and Xieyov, marker fragments of the Pi-b and Pi-ta genes were identified, and in samples IRIS 251-53324-Takanari and K107-11 (Lider / Takanari), the simultaneous presence of amplification of target fragments of the Pi-z and Pi-b genes was identified. These samples are potentially the most valuable donors of these genes.

\section{Discussion}

When studying the phenological and morpho-biological characteristics of Chinese rice forms in the conditions of Krasnodar rice cultivation, the following regularities were revealed:

- the growing season of the studied forms varied from 98 to 155 days, i.e. both early maturing and very late maturing forms were identified. The shape of the bush was predominantly erect;

- by the shape of the panicle, the samples varied from compact to medium spread;

- in terms of plant height, the Chinese lines were generally characterized as short, while the Russian standard variety Pobeda 65 had medium-sized plants, and the Russian variety Avangard - tall $(110-119 \mathrm{~cm})$.

All the studied samples under the conditions of the Kuban showed plant resistance to lodging.

Against the natural infectious background, the Chinese varieties Kendao 34, Ronguang, Tianjing 1 and the Pi 9-177 line were moderately resistant to the Krasnodar population of the blast pathogen. Visual assessments and description of rice varieties in the collection nursery were carried out throughout the growing season, for each individual trait in a certain phase. The study of collection samples for a number of morphological and biological traits showed their significant variability.

Position of the flag leaf in Chinese samples is from vertical (5-10 degrees) to horizontal (65-80 degrees). The length of the flag leaf varies in the range of 13-40 cm, and the width in the range of $0.8-1.8 \mathrm{~cm}$. In most of the studied Chinese samples, the flag leaf was medium sized and long.

The study of the elements of productivity made it possible to characterize this trait in Chinese rice samples under the conditions of the Kuban. The trait "panicle length" is a persistent genetic trait that correlates with plant height, panicle density and productivity, which almost completely lacks modification and ecological variability. According to the CMEA classifier, this trait is differentiated in rice: less than $10 \mathrm{~cm}$ - short panicle; $11-15$ $\mathrm{cm}$ - medium; 16 - $25 \mathrm{~cm}$ - long; more than $25 \mathrm{~cm}$ - very long.

According to table 3, most of the studied Chinese samples are characterized by a long panicle, while the indicator of the trait "panicle length" varied in the range of 13.2-22.5 cm. The trait "Total number of spikelets in a panicle" shows potential productivity of rice panicle, different yields of rice varieties are mainly determined by the unequal productivity of their panicles, associated with a different number of grains and their absolute weight (1000 pieces). The samples may be differentiated into dense, medium dense or loose 
varieties. The range of variability of the "panicle density" trait in the studied Chinese samples ranged from 4.1 to $12.3 \mathrm{pcs} / \mathrm{cm}$.

The species gradation of the trait "mass of grain from panicle" is presented in the collection nursery by ranks with an average level of severity of the trait. Depending on the genotype, the range of variability of this trait in the studied Chinese rice samples ranged from 1.33 to 3.7 grams. The value of the trait "mass of grain from plant" in the studied varieties varied within $2.4-4.7$ grams. The mass of 1000 grains in the studied Chinese samples is at the low and medium levels. Increased grain size was formed by varieties Kendao 34, Liaokai 79, Kenddao 8. Varieties Longgeng 39, Liaoxing 21, Liaoxing 401, Gangyu 129, Ganguan 8, Longjing 3, Liaojing 168, HY11 and line Pi 9-177 should be noted in terms of panicle productivity.

According to the data in table 3, it is also seen that rice varieties BL 122, Gumei 4, Digu turned out to be moderately resistant to spikelets shattering ( 5 points), which is an undesirable trait in the breeding process.

Thus, as a result of phenotyping of rice samples of Chinese breeding for a complex of morphological, phenological and economically valuable traits in the environmental conditions of the Kuban, experimental data were obtained for the formation of a database.

The study of the intraspecific diversity of Oryza sativa L. by a complex of traits made it possible to reveal polymorphism of traits and to identify the genotypes of Chinese rice that are promising for Russian breeding programs. Local rice varieties adapted to the conditions of the region served as a benchmark for comparing the indicators of traits of introduced Chinese varieties.

Experimental haploidy was used for genetic stabilization of the breeding material.

When introducing the studied Chinese genotypes into the anther culture, it was taken into account that the production efficiency of doubled haploids, including rice, is influenced by many factors, the most significant are: the stage of microspore development, the genotype of the donor plant, the preparation of plant material, the composition of nutrient media during anther cultivation / microspores and during plant regeneration from calli / embryoids, conditions for the adaptation of regenerants to non-sterile conditions.

In the course of optimization of cultivation technology of isolated rice anthers in vitro for the successful production of androgenic haploids, it is important to establish a critical period in the development of a microspore, characterized by certain physiological and biochemical events, when it is possible to switch its development to the path of androgenesis. For this, before introduction into the culture in vitro, a cytological assessment of the state of microspores was carried out and the relationship of their development with the morphological traits of the panicle was compared. It has been established that in rice the mononuclear and early binuclear stages of microspore development are optimal for callus formation. In the course of the experiment, a correlation was revealed between the stage of pollen development and the position of the rice panicle during the booting period, which made it possible to visually record the optimal stage of selection of explants (anthers) by morphological characters without resorting to cytological control.

According to the results of cytological studies, it was determined that for inoculation of anthers, panicles located in the sheath of the leaf should be selected, while the distance between the flag and the second leaf is $5-7 \mathrm{~cm}$ (2-3 days before sprouting); flower scales are light green; the length of the anthers is $2.0-2.5 \mathrm{~mm}$. Microspores in the anther of such rice panicles are capable, under in vitro conditions, of switching from the gametophytic developmental pathway to an abnormal development, as a result of which callus is induced, in which foci of meristem cells and / or embryoids are subsequently formed with subsequent development into androgenic plants. The experimental data obtained made it possible to establish that the processes of morphogenesis in Chinese samples began on the 10-20th day after the transfer of callus tissues to regenerating media and cultivation in the 
light. The highest regenerative capacity was possessed by a 20-30-day-old dense, white, fine-grained nodular callus of a white or light yellow shade with white blotches. Its characteristics corresponded to the "embryoidogenic callus", which consists of round, small cells with a dense cytoplasm and a large nucleus, which is typical for meristem cells. With an increase in the time of cultivation of pollen callus, its morphogenetic potential and ability to induce shoot formation decreased due to cell degradation because of progressive tissue necrosis. Therefore, to provoke morphogenetic potencies and increase the yield of green regenerants, callus was passaged on fresh nutrient media every 20-30 days. Viable rice regenerants from morphogenic types of callus were obtained from sample Liaojing 168. Plants were formed according to the type of embryoidogenesis and hemorrhagic genesis. In embryoids / gemstones, coleoptile, shoot growth points with leaf rudiments, and the germinal root meristem were established. Plants obtained through anther culture are rooted in liquid nutrient media and planted in vessels with soil for adaptation to ex vitro conditions.

Identification of regenerants ploidy obtained in anther culture was carried out for early detection of plants with a haploid set of chromosomes and timely transferring them to the diploid level. In some androgenic rice plants, spontaneous diploidization occurred through endomitosis of haploid callus cells, as a result of which homozygous forms of the studied samples were obtained. Some of the regenerants had a haploid set of chromosomes $(12 \mathrm{n})$, which was confirmed by cytological studies. Such plants were characterized by short stature, reduced size of vegetative and generative organs, an increased number of spikelets per panicle, and were sterile.

Phytopathological evaluation (phenotyping according to the trait "resistance to the Krasnodar population of blast pathogen") showed that the varieties of Chinese breeding mainly showed an intermediate type of reaction. Variety Kendao 34 showed itself as susceptible. Varieties Tongyu 401 and Liojing 168 - as resistant. These varieties are valuable breeding resource included in the program of crosses with Russian varieties to develop domestic rice genotypes with long-term resistance to blast.

Molecular genetic identification of blast resistance genes in the studied rice samples is presented in Figures 1, 2, 3, which shows electrophoregrams of PCR products for DNA gene markers, Pi-z, Pi-ta and Pi-b.

On the electrophoretogram, target fragment for the Pi-z gene (Figure 1), about 260 base pairs in size, is identified in two standard samples (K1 and K2), as well as in some of the analyzed samples: Long jing 13, VNIIR6753, IRIS 251-53324 -Takanari, In total, in the studied sample of rice varieties, a fragment corresponding to the dominant allele of this gene was found in five samples: Long jing 13, VNIIR6753, IRIS 251-53324-Takanari, Tong Jing 29, K107-11 Lider / Takanari.

For the Pi-ta gene, a target fragment of about 400 base pairs corresponding to the dominant allele was found in 12 introductory samples: Long jing 16, Long jing 20, Mu 07 1111, Deshan B, Long jing 18, Dong 415, Long jing 15, Long jing 13, Mu 07-1049, Long jing 12, Xieyov, Dong Nong V7. The results for some of the samples are shown in Figure 2 .

When carrying out PCR identification of alleles of the Pi-b gene, a codominant DNA marker was used, which makes it possible to identify both the dominant allele and the recessive and heterozygosity at the locus of this gene. The size of the PCR product specific for the dominant allele is 490 base pairs, for the recessive allele - 249 base pairs. From the electrophoretogram in Figure 3, it can be seen that in the control sample, as well as in samples $1,4,6,8$, and 9 , a product of about 490 base pairs is amplified, which corresponds to the size of the fragment in the dominant allele of the gene. In the rest of the samples, except for sample No. 13, the fragment size is about 250 base pairs, which corresponds to the target size for the recessive allele ( 249 base pairs). The amplification pattern of sample 
№. 13 (K04207) differs from amplification in all studied samples, which may indicate the presence in the Pi-b allele sequence of structural polymorphism in the primer annealing regions.

The functional activity of this allele can be detected by performing phytopathological testing with a compatible race of the fungal pathogen.

An amplification fragment corresponding to the dominant allele of this gene was detected in 10 samples: Long jing 16, G-46-B, VNIIR 40 / 4-1, Xieyov, Lider / Takanari-2, IRIS 251-53325 Takanari, 933B, K107-11 Lider/ Takanari, IRIS 251-53324 Takanari, 611 B.

Confirmation of the presence of dominant alleles of the identified genes in the studied samples can be performed by phytopathological testing with compatible races of the pathogen (Magnaporthe grisea (T.T. Hebert) M.E. Barr). In this case, the functional activity of the identified alleles will be confirmed. Along with this, elucidation of the genealogy data of the samples will also allow obtaining confirmation of the presence of dominant alleles of the desired genes in the case of identifying known donors of these genes in them as one of the parental forms.

\section{Conclusion}

Within the framework of this study, the first Russian-Chinese joint program for development of rice varieties with long-term blast resistance was launched on the basis of the exchange of rice germplasm and the subsequent comprehensive study of the obtained breeding samples, hybridization of Russian and Chinese varieties with specified traits, etc. Its successful implementation will largely determine the directions and success of further scientific cooperation.

The study was carried out with the financial support of the RFBR grant 19-516-53001 GFEN_a "Development and use of pre-breeding rice resources with pyramided genes with a wide spectrum of resistance to blast causative agent".

\section{References}

1. Vasudevan K, Vera Cruz C M, Gruissem W and Bhullar NK 2014 Front. Plant Sci. 5(505) doi: 10.3389/fpls.2014.00505

2. Zhi-Kang Li, Fan Zhang 2013 Current Opinion in Plant Biology 16 261-9 doi.org/10.1016/j.pbi.2013.03.008

3. Godfray H C J, Beddington J R, Crute I R et al C 2010 Science 327 812-18 DOI: 10.1126/science. 1185383

4. Leach J E, Davidson B Liu et al 2007 Rice Genet. 12 191-2007

5. Kostylev P I, Krasnova E V, Red'Kin A A, Dubina E V, Mukhina Zh M 2017 Ecological Genetics 15 15354-63

6. Fukuoka S, Mizobuchi R, Saka N, Suprun I, Matsumoto T, Okuno K, Yano M 2012 Theor. Appl. Genet. 125(3) 551-9

7. Jeung J U, Kim B R, Cho Y C, Han S S, Moon H P, Lee Y T and Jena K K 2007 Theor. Appl. Genet. 15 1163-77

8. Korotenko T, Mukhina Zh, Garkusha S, Savenko E, Bragina O 2019 IOP Conference Series: Earth and Environmental Science 403(1) 012004

9. Victoria C, Lapitan D, Edilberto Redoña, Toshinori Abe, Darshan S 2009 Brar Field Crops Research. 112 222-8 
10. Savenko E, Mukhina Zh, Glazyrina V, Korotenko T, Garkusha S 2019 IOP Conference Series: Earth and Environmental Science 403(1) 01

11. Mishra Rukmini, Jwala Gundimeda, Rao Narashima, Ravi Nageswara Rao, Pankaj Kaushal 2015 Rice Science 22 290-9

12. Mishra Rukmini, Gundimeda Jwala, Narashima Rao 2016 Constraints and Future Prospects Rice Science 23 57-68

13. Wang Li, Gang Lin, Zhao Deming, Wang Feng, Chen Jiabin 2011 Journal of Northeast Agricultural University (English edition) 18 13-17

14. Du Yixin, Ruan Hongchun, Shi Niuniu 2016 Journal of Plant Protection 43(3) 442-51

15. Li C Y, Li J B, Liu L et al. 2007 Molecular Ecology Notes 131 144-152 